\title{
Cytotoxicity and acetylcholinesterase inhibitory activity of an isolated crinine alkaloid from Boophane disticha (Amaryllidaceae)
}

\author{
Emmanuel Adekanmi Adewusi ${ }^{\mathrm{a}}$, Gerda Fouche ${ }^{\mathrm{b}}$ and Vanessa Steenkamp ${ }^{\mathrm{a}^{*}}$ \\ ${ }^{a}$ Department of Pharmacology, Faculty of Health Sciences, University of Pretoria, Private Bag \\ X323, Arcadia 0007, South Africa. \\ ${ }^{\mathrm{b}}$ Natural Product Chemistry Group, Biosciences, Council for Scientific and Industrial Research, \\ PO Box 395, Pretoria, 0001
}

*Corresponding Author

Prof. Vanessa Steenkamp

Department of Pharmacology

Faculty of Health Sciences

University of Pretoria

Private Bag X323, Arcadia 0007

South Africa

Tel: +27 123192547

Fax: +27 123192411

Email: Vanessa.steenkamp@up.ac.za 


\section{Graphical Abstract}

Boophane disticha bulbs

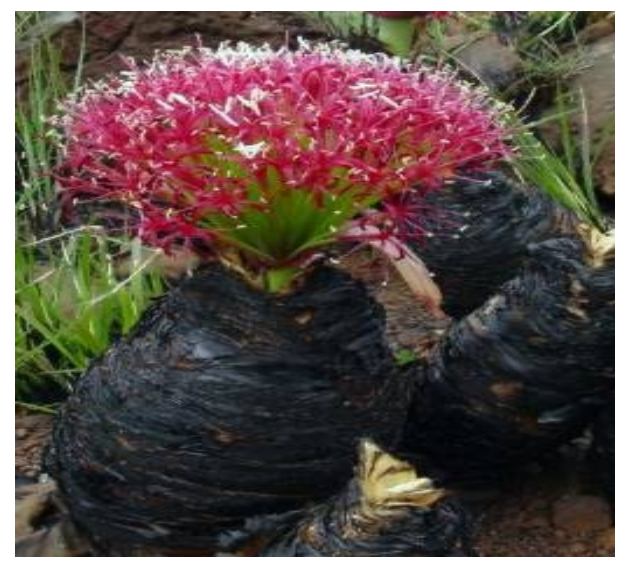

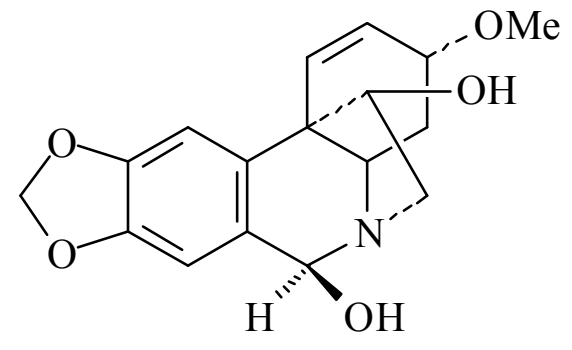

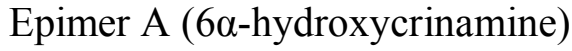
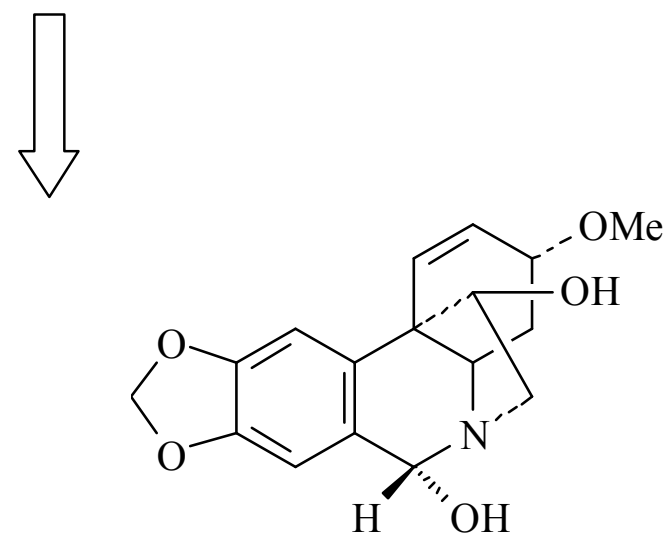

Epimer B (6ß-hydroxycrinamine) 


\begin{abstract}
Ethnopharmacological relevance: Boophane disticha of the family Amaryllidaceae is used traditionally in southern Africa in the treatment of several neurological disorders.

Aim of the study: Although acetylcholinesterase (AChE) inhibitory activity has been reported for this plant, the aim of the study was to identify and characterize the compound responsible for this activity using bioassay guided fractionation. Toxicity of the isolated compound was also assessed.
\end{abstract}

Materials and methods: Bioassay guided isolation of the active compound from the methanol extract was carried out using column chromatography, TLC and preparative thin layer chromatography. Structural elucidation was carried out using high field 1D and 2D NMR and mass spectroscopy. AChE inhibitory activity was determined using the Ellman's colorimetric method. Cytotoxicity assessment was determined in human neuroblastoma (SH-SY5Y) cells using the MTT and neutral red uptake assays.

Results: The data obtained from the integration of the ${ }^{1} \mathrm{H}$ spectra confirmed the compound to be a 3:1 mixture of two epimers, with epimer A, $6 \alpha$-hydroxycrinamine as the major epimer. The $\mathrm{IC}_{50}$ value for $\mathrm{AChE}$ inhibitory activity of the compound was $445 \mu \mathrm{M}$. The compound was observed to be cytotoxic in both the MTT and neutral red assays with $\mathrm{IC}_{50}$ values of 54.5 and $61.7 \mu \mathrm{M}$, respectively.

Conclusion: The present study describes for the first time, the isolation of 6-hydroxycrinamine, a crinine alkaloid, from the methanol extract of the bulbs of $B$. disticha. Although this compound possessed AChE inhibitory activity, it was found to be toxic to the neuroblastoma cells. 
Quantitative structure-activity relationship studies could be carried out to modify the structure in order to make it less toxic and improve its activity.

Keywords: Acetylcholinesterase, Amaryllidaceae, Boophane disticha, cytotoxicity, SH-SY5Y cells, 6-hydroxycrinamine

\section{Introduction}

Aging is one of the factors which results in the dysfunction of normal cellular regulation, affecting both central nervous and immune systems (Kawahami et al., 1999; Yu et al., 2005). It is an important risk factor of several neurodegenerative diseases including Alzheimer's disease (AD) ( $\mathrm{Yu}$ et al., 2005). $\mathrm{AD}$ is a neurodegenerative disorder with increasing prevalence in the elderly population in the western world and the most common cause of age-related intellectual impairment occurring after the age of 60 (Silva et al., 2004). Treatment of AD has largely involved replacement of neurotransmitters that are known to be lacking, mostly based on the inhibition of acetylcholinesterase (AChE), an important approach that is founded on the cholinergic hypothesis for the disease (Francis et al., 1999; Konrath et al., 2012). The drugs approved so far for $\mathrm{AD}$ therapy act by counteracting the acetylcholine deficit and thus, improve levels of the neurotransmitter in the brain (Heinrich and Teoh, 2004; Ferreira et al., 2006). The molecular basis of the drugs used so far take advantage of their action as acetylcholinesterase inhibitors (Heinrich and Teoh, 2004). However, these drugs are extremely limited; possess considerable side effects related to cholinergic stimulation in brain and peripheral tissues and cause hepatotoxicity which is related to tacrine (Knapp et al, 1994; Thompson et al., 2004; Fang 
et al., 2008). Considering the complex pathology of $\mathrm{AD}$, research is ongoing to develop new compounds and leads which are not toxic and have potential for use in the treatment of the disease.

Boophane disticha (L.f.) Herb. belongs to the family Amaryllidaceae. It is an attractive, deciduous bulbous plant with a thick covering of dry scales above the ground and is widely distributed in Africa, ranging from Sudan in the north to the Western Cape Province in the south (Wrinkle, 1984). Decoctions of bulb scales are given to sedate violent, psychotic patients (van Wyk and Gericke, 2000) and bulb infusions are reported to be used to treat mental illness (Sobiecki, 2002).

Several alkaloids from this plant have been isolated and identified (Figure 1) (Hautch and Stauffacher, 1961). Buphanidrine, buphanamine and distichamine have been reported to have affinity to the serotonin transporter indicating their potential in treatment of depression and anxiety (Sandager et al., 2005; Neergaard et al., 2009). Also, acetylcholinesterase inhibitory activity has been reported for this plant (Adewusi, 2012). The aim of the study was to identify and characterize the compound responsible for the AChE inhibitory activity using bioassay guided fractionation. Toxicity of the isolated compound was determined using both the 3-[4, 5dimethylthiazol-2-yl]-2, 5-diphenyltetrazolium bromide (MTT) and neutral red assays. The neutral red assay was included as it does not rely on a reduction reaction to determine viability, thereby reducing the possibility of obtaining false positive results in the presence of antioxidants or other reductive agents (van Tonder, 2011). 


\section{Materials and methods}

\subsection{General}

Nuclear Magnetic Resonance (NMR) spectroscopy was performed using a $600 \mathrm{MHz}$ Varian NMR. Structural characterizations were carried out using a combination of one dimensional (1D) $\left({ }^{1} \mathrm{H},{ }^{13} \mathrm{C}\right)$ and various two dimensional (2D) experiments. The $2 \mathrm{D}$ experiments carried out included Distortionless Enhancement by Polarisation Transfer (DEPT), Correlation Spectroscopy (COSY), Heteronuclear Single Quantum Coherence (HSQC) and Heteronuclear Multiple Bond Correlation (HMBC). Chemical shifts are reported in units of $\delta(\mathrm{ppm})$ and coupling constants $(J)$ are expressed in Hz. UV-VIS detection was done on a WATERS PDA scanning from $200-600$ nm. Mass spectrometry (MS) detection was performed using a WATERS SQD scanning from $100-1200 \mathrm{~m} / \mathrm{z}$ with polarity (+/-) switching. Silica gel $60(0.063-0.2 \mathrm{~mm})$ was used for column chromatography, while pre-coated glass plates (Merck, SIL G-25 UV $254,20 \mathrm{~cm}$ x $20 \mathrm{~cm}$ ) were used for thin layer chromatography (TLC) and preparative TLC. Spots on the TLC plates were detected under UV light at short wave $(250 \mathrm{~nm})$ and long wave $(365 \mathrm{~nm})$ lengths, and by vanillin- $\mathrm{H}_{2} \mathrm{SO}_{4}$ and Dragendorff's reagent. Acetylthiocholine iodide (ATCI), acetylcholinesterase (AChE) and 5,5'-dithiobis [2-nitrobenzoic acid] (DTNB) purchased from Sigma, were used for the determination of AChE inhibitory activity while MTT and neutral red dye also purchased from Sigma were used for the cytotoxicity assays. Human neuroblastoma (SH-SY5Y) cells were purchased from American cell type collection culture (ATCC CRL-2266, Rockville, MD, USA). 


\subsection{Plant material}

Bulbs of Boophane disticha (L.f.) Herb. (Amaryllidaceae) were a gift from the South African National Biodiversity Institute, Pretoria.

\subsection{Extraction and bio-assay guided isolation of alkaloid}

Plant material was cut into small pieces and air-dried at room temperature. Dried material was ground to a fine powder using an Ika Analytical Mill (Staufen, Germany), and stored at ambient temperature in the dark till use. $250 \mathrm{~g}$ of the powdered plant material was extracted with 2.5 $\mathrm{L}$ of methanol for $24 \mathrm{~h}$ while shaking. The extracts were filtered, concentrated using a rotary vacuum evaporator and further dried under reduced pressure. The residue $(6 \mathrm{~g})$ was subjected to column chromatography on silica gel by gradient elution with $\mathrm{CHCl}_{3}$ and $\mathrm{CHCl}_{3} / \mathrm{MeOH}$ mixtures starting from 100:0 until 70:30 as eluent to give 50 fractions. The fractions were pooled together based on the similarity in their $\mathrm{R}_{\mathrm{f}}$ values on a thin-layer chromatography plate to give four sub-fractions. Each sub-fraction was tested for their inhibition of AChE on the TLC plate as described below. Sub-fractions 2 and 3 were the only active sub-fractions. Sub-fraction 2 was further chromatographed on a silica gel column using a stepwise gradient mixture of $\mathrm{CHCl}_{3}$ : $\mathrm{MeOH}$ starting from 95:5 until 75:25 as eluent to give another set of 30 fractions and tested for activity. Of this sub-fraction, only fractions 1,4 and 8 were active.

Sub-fraction 3 was also further chromatographed on a silica gel column using a stepwise gradient mixture of $\mathrm{CHCl}_{3}: \mathrm{MeOH}$ starting from 95:5 until 75:25 as eluent, to give 23 fractions which were also tested for activity. Fractions $5,14,15$ and 16 were active and had similar $\mathrm{R}_{\mathrm{f}}$ values as fractions 1, 4 and 8 from sub-fraction 2 , and so these seven fractions were combined 
and further purified. Preparative TLC yielded 6-hydroxycrinamine $(20 \mathrm{mg})$, obtained as yellow crystals with a yield of $0.33 \%$. The isolation of 6-hydroxycrinamine is summarized schematically in Figure 2. The identity of 6-hydroxycrinamine was confirmed through NMR and MS analysis. Data obtained from mass spectroscopy was analysed using MassLynx 4.1 (SCN 704) software and the fragmentation patterns of the compounds isolated were identified with the Agilent ChemStation software which has a National Institute of Standards and Technology (NIST) library of mass fragmentations.

\subsection{Determination of acetylcholinesterase inhibition}

\subsubsection{TLC assay}

The TLC assay, which is a qualitative assay, was carried out as described by Adsersen et al. (2007). Fractions or isolated compound $(3 \mu \mathrm{l})$ were applied to TLC plates (silica; $10 \mathrm{~cm} \times 10$ $\mathrm{cm})$. After development with chloroform: methanol (8:2), the plates were sprayed with $5 \mathrm{mM}$ ATCI and $5 \mathrm{mM}$ DTNB in $50 \mathrm{mM}$ Tris- $\mathrm{HCl}$ buffer $(\mathrm{pH} 8)$ until the silica was saturated with the solvent. The plates were then sprayed with $3 \mathrm{U} / \mathrm{ml} \mathrm{AChE}$ which was dissolved in $50 \mathrm{mM}$ Tris$\mathrm{HCl}$ buffer ( $\mathrm{pH}$ 8). Galanthamine was used as a positive control, as it is a known AChE inhibitory compound (Heinrich and Teoh, 2004). A yellow background with white spots was considered indicative of $\mathrm{AChE}$ inhibiting fractions/compounds.

False-positive reactions were eliminated by the method of Rhee et al. (2003). A TLC plate identical to the one described above was prepared. The developed TLC plate was sprayed with 5 $\mathrm{mM}$ DTNB in $50 \mathrm{mM}$ Tris- $\mathrm{HCl}(\mathrm{pH}$ 8). Plates were then sprayed with $5 \mathrm{mM}$ ATCI and $3 \mathrm{U} / \mathrm{ml}$ 
AChE in Buffer A. A yellow background with white spots was indicative of false positive reactions.

\subsubsection{Micro-plate assay}

Inhibition of acetylcholinesterase activity was quantified using Ellman's colorimetric method as modified by Eldeen et al. (2005). Three buffers were prepared for the assay; Buffer A (50 mM Tris- $\mathrm{HCl}, \mathrm{pH} 8)$, Buffer B (50 mM, pH 8, containing $0.1 \%$ bovine serum albumin) and Buffer C (50 mM Tris- $\mathrm{HCl}, \mathrm{pH} 8$, containing $0.1 \mathrm{M} \mathrm{NaCl}$ and $0.02 \mathrm{M} \mathrm{MgCl}_{2} \cdot 6 \mathrm{H}_{2} \mathrm{O}$ ). Into a 96-well plate was placed: $25 \mu 1$ of $15 \mathrm{mM}$ ATCI in water, $125 \mu 1$ of $3 \mathrm{mM}$ DTNB in Buffer C, $72.5 \mu 1$ of Buffer B and $2.5 \mu 1$ of pure compound dissolved in DMSO at concentrations ranging from 0.013 $\mu \mathrm{M}$ to $1.63 \mu \mathrm{M}$. Absorbance was measured spectrophotometrically (Labsystems Multiscan EX type 355 plate reader) at $405 \mathrm{~nm}$ every $45 \mathrm{~s}$, three times consecutively. Thereafter, AChE $(0.2$ $\mathrm{U} / \mathrm{ml}$ ) was added to the wells and the absorbance measured five times consecutively every $45 \mathrm{~s}$. Galanthamine served as the positive control. Any increase in absorbance due to the spontaneous hydrolysis of the substrate was corrected by subtracting the absorbance before adding the enzyme from the absorbance after adding the enzyme. The percentage inhibition was calculated using the equation:

Inhibition $(\%)=1-\left(\mathrm{A}_{\text {sample }} / \mathrm{A}_{\text {control }}\right) \times 100$

Where $A_{\text {sample }}$ is the absorbance of the sample extract and $A_{\text {control }}$ is the absorbance of the blank [extraction solvent in Buffer A (50 mM Tris- $\mathrm{HCl}, \mathrm{pH} 8)$ ]. Extract concentration providing 50\% inhibition $\left(\mathrm{IC}_{50}\right)$ was obtained from the graph of the percentage inhibition against extract concentration. 


\subsection{Cells and cell culture}

SH-SY5Y (ATCC CRL-2266) cell lines were used for the cytotoxicity studies. Cells were cultured in Ham's F-12 supplemented with 2\% heat-inactivated fetal bovine serum, penicillin $(100 \mathrm{U} / \mathrm{ml})$ and streptomycin $(100 \mu \mathrm{g} / \mathrm{ml})$ at $37^{\circ} \mathrm{C}$ in a humidified incubator at $95 \%$ air and $5 \%$ $\mathrm{CO}_{2}$. For use in the assay, the cells were trypsin-treated for $10 \mathrm{~min}$, decanted from culture flasks and centrifuged $(200 \mathrm{~g}, 10 \mathrm{~min})$. The pellet was re-suspended in $1 \mathrm{ml}$ Fetal calf serumsupplemented Ham's F-12 medium and enumerated by staining with trypan blue. The cells were

diluted to a concentration of $1 \times 10^{5}$ cells/well in Ham's F-12 medium and $100 \mu$ lof the cell suspension plated into each of the wells of a 96-well microtiter plate. $80 \mu \mathrm{l}$ of Ham's F-12 medium was added and plates were then incubated for $1 \mathrm{~h}$ at $37^{\circ} \mathrm{C}$ in a humidified incubator at $95 \%$ air and $5 \% \mathrm{CO}_{2}$ to allow for cellular re-attachment.

\subsection{Cytotoxicity studies}

\subsubsection{MTT assay}

The MTT assay as described by Mossmann (1983) was used to measure cell viability. The principle of the assay is based on generation of formazan (a blue product), in the mitochondria of active cells which is measured by photometric techniques (Hansen et al., 1989). The cells were plated into 96-well culture plates, as described above, and treated after $1 \mathrm{~h}$ with various concentrations of the alkaloid (dissolved in $0.3 \% \mathrm{v} / \mathrm{v}$ DMSO), ranging from $3.125 \mu \mathrm{M}$ to $400 \mu \mathrm{M}$ for $72 \mathrm{~h}$. The vehicle $(0.3 \% \mathrm{v} / \mathrm{v}$ DMSO) was used as control. Thereafter, $20 \mu \mathrm{l}$ of MTT solution $(5 \mathrm{mg} / \mathrm{ml}$ ) was added to the wells and further incubated for $3 \mathrm{~h}$. $50 \mu \mathrm{l}$ of solution containing $30 \%$ (w/v) $N, N$ - dimethylformamide and $20 \%$ sodium dodecyl sulphate in water was then added to 
breach the cells and dissolve the formazan crystals. The plates were incubated overnight at $37^{\circ} \mathrm{C}$, after which absorbance was measured at 570-630 nm using a microtiter plate reader (Labsystems Multiscan EX type 355 plate reader). Wells without cells were used as blanks and were subtracted as background from each sample. Cytotoxicity results are expressed as the percentage cell survival compared to the untreated control using a dose response curve. Extract concentration providing 50\% inhibition $\left(\mathrm{IC}_{50}\right)$ was calculated from the graph of inhibition percentage versus extract concentration.

\subsubsection{Neutral red assay}

The neutral red uptake assay as described by Borenfreund and Puerner (1984), was also used to assess cell viability. This method is based on the determination of the accumulation of the neutral red dye in the lysosomes of viable, uninjured cells. The cells were plated into 96-well culture plates, as described above, and treated after $1 \mathrm{~h}$ with various concentrations of the alkaloid (dissolved in $0.3 \% \mathrm{v} / \mathrm{v}$ DMSO), ranging from $3.125 \mu \mathrm{M}$ to $400 \mu \mathrm{M}$ for $72 \mathrm{~h}$. The vehicle $(0.3 \% \mathrm{v} / \mathrm{v}$ DMSO) was used as control. Thereafter, $150 \mu 1$ of neutral red dye $(100 \mu \mathrm{g} / \mathrm{ml})$ dissolved in serum free medium ( $\mathrm{pH} 6.4$ ), was added to the culture medium for $3 \mathrm{~h}$ at $37^{\circ} \mathrm{C}$. Cells were washed with Phosphate Buffered Saline (PBS), and $150 \mu \mathrm{l}$ of elution medium (EtOH/AcCOOH, 50\%/1\%) was added followed by gentle shaking for 60 min, so that complete dissolution could be achieved. Absorbance was recorded at 540-630 nm using a microtiter plate reader (Labsystems Multiscan EX type 355 plate reader). Cytotoxicity results are expressed as the percentage cell survival compared to the untreated control using a dose response curve. Extract concentration providing $50 \%$ inhibition $\left(\mathrm{IC}_{50}\right)$ of cell death was calculated from the graph of inhibition percentage versus extract concentration. 


\subsection{Statistical analysis}

Tests were carried out where possible at least in triplicate and on three different occasions. The results are reported as mean \pm standard deviation (S.D.). Standard curves were generated and calculation of the $50 \%$ inhibitory concentration $\left(\mathrm{IC}_{50}\right)$ values was done using GraphPad Prism Version 4.00 for Windows (GraphPad Software Inc.). Cytotoxicity results are expressed as the percentage cell survival compared to the untreated control using a dose response curve. Data obtained from mass spectroscopy were analysed using MassLynx 4.1 (SCN 704) software and the fragmentation patterns of the compounds isolated were identified with the Agilent ChemStation software which has a National Institute of Standards and Technology (NIST) library of mass fragmentations.

\section{Results}

Bioassay guided fractionation of the extracts was carried out and each fraction was screened to determine the presence of $\mathrm{AChE}$ inhibitory compounds using the qualitative TLC assay. From the bioassay guided fractionation (Figure 2), yellow crystals were isolated which reacted with Dragendorff's reagent to give an orange colour as a qualitative test to confirm that it is an alkaloid. MS data showed the molecular ion $[\mathrm{M}]^{+}$peak as the base peak at $\mathrm{m} / \mathrm{z} 318$ which corresponds to the molecular formula $\left(\mathrm{C}_{17} \mathrm{H}_{19} \mathrm{NO}_{5}\right)$. The signals obtained from both ${ }^{1} \mathrm{H}$ and ${ }^{13} \mathrm{C}$ NMR spectra were complex suggesting that the isolated compound was a mixture of two epimers. Analyses of both the NMR and MS data revealed that the structure of the isolated compound was 6-hydroxycrinamine and its epimer (Figure 3). The NMR data is given in Table 1 $\left({ }^{1} \mathrm{H}\right.$ NMR) and Table $2\left({ }^{13} \mathrm{C}\right.$ NMR $)$. 
AChE inhibitory activity of 6-Hydroxycrinamine was qualitatively determined using the TLC method. The compound showed activity as evident by the white spots on a yellow background and no false-positive reactions were seen. The $\mathrm{IC}_{50}$ value of 6-hydroxycrinamine for inhibition of

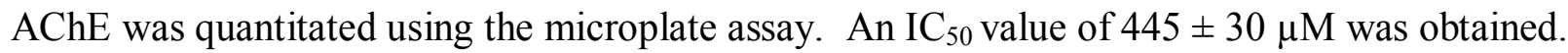

6-Hydroxycrinamine was further tested to determine its effect on the viability of human neuroblastoma (SH-SY5Y) cell lines, as an assessment of its cytotoxicity. The compound was observed to have a dose-dependent effect on viability. Results obtained from both cytotoxicity assays (MTT and neutral red uptake), were comparable (Figure 4). Low $\mathrm{IC}_{50}$ values of $54.5 \pm 2.6$ $\mu \mathrm{M}$ and $61.7 \pm 4.5 \mu \mathrm{M}$ were obtained for the MTT and neutral red assays respectively, which is an indication of the toxicity of 6-hydroxycrinamine.

\section{Discussion}

The NMR data obtained was compared to that of the published data on 6-hydroxycrinamine

(Viladomat et al., 1996). The data obtained from the integration of the ${ }^{1} \mathrm{H}$ spectra confirmed the compound to be a 3:1 mixture of two epimers, with epimer A, $6 \alpha$-hydroxycrinamine as the major epimer. Although the same alkaloid has been isolated from Brunsvigia orientalis, the mixture differed in ratio, being a 2:1 mixture of epimers A/B (Viladomat et al., 1996). We observed from our extensive literature search that $6 \alpha$-hydoxycrinamine and its epimer has not previously been isolated from any species of Boophane. Epimer A was the major epimer and the epimeric difference is found at the benzylic position (C-6). Epimer A shows H-6 in the $\alpha$ - position and hydroxyl group in the $\beta$ - position while epimer B shows H-6 in the $\beta$ - position and hydroxyl group in the $\alpha$ - position. In both epimers, the small coupling constant between $\mathrm{H}-2$ and $\mathrm{H}-3$ and 
the large one between $\mathrm{H}-4 \alpha$ and $\mathrm{H}-3$ shows that there is a cis-relationship between the C-3 pseudoequatorial substituent and the 5,10b-ethanobridge. The 5, 10b-ethanobridge which occurs in the $\alpha$-position shows that 6-hydroxycrinamine is a crinine-type alkaloid. A C-11 hydroxyl substituent is observed at the exo-position and this is due to the de-shielding effect on $\mathrm{H}-11$ and the long range W-coupling between H-11 and H-4a. Epimer A was observed to have a benzylic proton $\mathrm{H}-6 \alpha$ as a singlet at $\delta 5.01$. In epimer $\mathrm{B}$, the proton $\mathrm{H}-6 \beta$ was observed at a lower field, as a singlet at $\delta 5.60$. In both epimers, C-9 was assigned at lower fields than C-8 because of its three-bond correlation with the methane proton H-7. The quaternary carbons C-6a and C-10a were ascribed by means of their correlations with the methine protons $\mathrm{H}-10$ and $\mathrm{H}-7$, respectively. Also, the singlets at $\delta 51.1$ and 50.7 were assigned to $\mathrm{C}-10 \mathrm{~b}$ of both epimers, considering their three-bond connectivity with H-2, H-4 and H-10. The total yield of alkaloids in the bulbs of $B$. disticha is $0.31 \%$. 6-hydroxycrinamine is a minor alkaloid and constitutes only $2.5 \%$ of total alkaloid content. The major alkaloids, buphanidrine and buphanamine, have been reported to constitute $19.4 \%$ and $14.1 \%$ of total alkaloid content, respectively (Hautch and Stauffacher, 1961).

The result obtained for the AChE inhibitory activity of the 3:1 mixture of the two epimers of 6-hydroxycrinamine in the present study is similar to that obtained by Elgorashi et al. (2004) for the epimer mixture with a 2:1 ratio, with an $\mathrm{IC}_{50}$ value of $490 \pm 7 \mu \mathrm{M}$. Concentrations of $\mathrm{AChE}$ inhibitory activity of $\leq 500 \mu \mathrm{M}$ are considered active (Wink, 2000). However, the high $\mathrm{IC}_{50}$ value compared to the control, galanthamine $(1.85 \pm 0.20 \mu \mathrm{M})$, indicates that 6hydroxycrinamine has weak activity. Several other crinine-type alkaloids have been isolated from other plants in the Amaryllidaceae family; crinine, epibuphanisine, crinamidine and epivittatine have been isolated from Crinum moorei (Elgorashi et al., 2001a); hamayne from $C$. 
macowanii (Elgorashi et al., 2001b); 3-O-acetylhamayne and crinamine from C. bulbispermum. These alkaloids have been screened for inhibition of $\mathrm{AChE}$ and similar to 6-hydroxycrinamine, they showed weak inhibition with $\mathrm{IC}_{50}$ values of $461 \pm 14 \mu \mathrm{M}, 547 \pm 5 \mu \mathrm{M}, 300 \pm 27 \mu \mathrm{M}, 553 \pm$ $3 \mu \mathrm{M}, 594 \pm 8 \mu \mathrm{M}, 239 \pm 9 \mu \mathrm{M}$ and $697 \pm 12 \mu \mathrm{M}$ for crinine, epibuphanisine, crinamidine, hamayne, 3-O-acetylhamayne, epivittatine and crinamine, respectively (Elgorashi et al., 2004). Despite its weak AChE inhibitory activity, 6-hydroxycrinamine still has the potential to be developed further for use in the treatment of $\mathrm{AD}$, as it can cross the blood-brain barrier (Eriksson et al., 2012). Passage across the blood-brain barrier has been reported to occur by passive diffusion and a study of compounds that are available in the CNS and cross the blood-brain barrier has shown that the molecular weight should be below 450, the number of $\mathrm{H}$-bond donors should be less than 3 , the number of acceptors should be less than 7 and the compounds should either be neutral and basic with pKa of 7.5-10.5 (Pajouhesh and Lenz, 2005). Taking the physicochemical properties and structure of 6-hydroxycrinamine into account: molecular weight of $317 \mathrm{~g} / \mathrm{mol}$, number of H-bond donors as 2, the number of acceptors as 6 and a pKa of 7.1 (Eriksson et al., 2012), this compound is a suitable candidate for the development of neuroprotective agents.

The SH-SY5Y cell line was chosen to assess the cytotoxicity of 6-hydroxycrinamine. This cell line has been widely used in experimental neurological studies, including analysis of neuronal differentiation, metabolism and function related to neurodegenerative and neuroadaptive processes, neurotoxicity and neuroprotection as it exhibits neuronal marker enzyme activity, specific uptake of norepinephrine and expresses one or more neurofilament proteins (Xie et al., 2010). In addition, the SH-SY5Y cells possess the capability of proliferating in culture for long periods without contamination, which is a prerequisite for the development of 
an in vitro cell model (Xie et al., 2010). The MTT and neutral red assays are two assays commonly used to determine cell viability (Pallant, 2010). MTT, is a pale yellow water-soluble salt which is converted to a water insoluble highly colored purple formazan in the mitochondria of living cells. The formazan crystals cannot permeate the cell membrane and accumulate inside healthy cells (Mossman, 1983). The accumulation of formazan is directly correlated to the activity of the mitochondria, giving a linear response between cell number or activity to the color intensity. Neutral red, a supravital dye relies on the principle of dye accumulation in the lysosomes and Golgi apparatus of viable, uninjured cells. It does not rely on a reduction reaction to determine viability, thereby reducing the possibility of making type 1 errors (false positives) in the presence of antioxidants or other reductive agents (van Tonder, 2011). Therefore both assays were included for the determination of cell viability in the present study.

Following medicinal administration, bulbs of $B$. disticha have been documented to cause fatal poisoning in humans (Du Plooy et al., 2001). It has been reported to cause sedation, hallucinations, irrational behavior and comatose states, which has been ascribed to its alkaloidal content (Botha et al., 2005). A low $\mathrm{IC}_{50}$ value was obtained for 6-hydroxycrinamine in both the MTT and neutral red assays. The cytotoxic effect of several crinine-type and similar alkaloids, have been reported. Lycorine, crinamine and augustine have been reported to demonstrate significant cytotoxic activity in 12 different cell lines (Likhitwitayawuid et al., 1993). Crinafolidine and crinafoline were observed to produce significant reduction in the viability and in vivo growth of S-180 ascites tumor cells (Tram et al., 2002). Amaryllidaceae alkaloids isolated from Crinum augustum and C. bulbispermum have been shown to exhibit cytotoxic activity on human leukemic Molt4 cells (Zvetkova et al., 2001). Criasiaticidine A and lycorine have been shown to be toxic to Meth-A (mouse sarcoma) and Lewis lung carcinoma (mouse carcinoma) 
tumor cell lines (Min et al., 2001). In addition, crinamine, hemanthamine and papyramine have been shown to be toxic to non-tumoral fibroblastic LMTK cells (Bastida et al., 2011).

In conclusion, the present study describes for the first time, the isolation of 6hydroxycrinamine, a crinine alkaloid, from the bulbs of Boophane disticha. The results indicate that this isolated compound possesses AChE inhibitory activity, supporting its use for treatment of neurological disorders. However, the compound was found to be toxic to neuroblastoma cells. Despite the toxicity of these crinine-type alkaloids, quantitative structure-activity relationship studies could also be carried out to modify the structures in order to make them less toxic and improve their activity.

\section{Acknowledgements}

We are grateful to Dr. Paul Steenkamp for assistance with the mass spectrometry analysis and the Department of Pharmacology, University of Pretoria for funding.

\section{References}

Adewusi, E.A., 2012. Doctoral thesis, In vitro effect of selected medicinal plants on $\beta$-amyloid induced toxicity in neuroblastoma cells. University of Pretoria, Pretoria, South Africa.

Adsersen, A., Kjølbye, A., Dall, O., Jäger, A.K., 2007. Acetylcholinesterase and butyrylcholinesterase inhibitory compounds from Corydalis cava Schweigg. \& Kort. Journal of Ethnopharmacology 113, 179-182. 
Bastida, J., Berkov, S., Torras, L., Pigni, N.B., de Andrade, J.P., Martínez, V., Codina, C., Viladomat, F., 2011. Chemical and biological aspects of Amaryllidaceae alkaloids. Recent Advances in Pharmaceutical Sciences, 65-100.

Borenfreund, E., Puerner, J.A., 1984. A simple quantitative procedure using monolayer cultures for cytotoxicity assays (HTD/NR-90). Journal of Tissue Culture Methods 9, 7-9.

Botha, E.W., Kahler, C.P., du Plooy, W.J., du Plooy, S.H., Mathibe, L., 2005. Effect of Boophone disticha on human neutrophils. Journal of Ethnopharmacology 96, 385-388.

Du Plooy, W.J., Swart, L., van Huysteen, G.W., 2001. Poisoning with Boophane disticha: a forensic case. Human and Experimental Toxicology 20, 277-278.

Eldeen, I.M.S., Elgorashi, E.E., van Staden, J., 2005. Antibacterial, anti-inflammatory, anticholinesterase and mutagenic effects of extracts obtained from some trees used in South African traditional medicine. Journal of Ethnopharmacology 102, 457-464.

Elgorashi, E.E., Drewes, S.E., van Staden, J., 2001a. Alkaloids from Crinum moorei. Phytochemistry 56, 637-640.

Elgorashi, E.E., Drewes, S.E., van Staden, J., 2001b. Alkaloids from Crinum macowanii. Biochemical Systematics and Ecology 29, 749-750.

Elgorashi, E.E., Stafford, G.I., van Staden, J., 2004. Acetylcholinesterase enzyme inhibitory effects of Amaryllidaceae alkaloids. Planta Medica 70, 260-262.

Eriksson, A.H., Rønsted, N., Güler, S., Jäger, A.K., Sendra, J.R., Brodin, B., 2012. In-vitro evaluation of the P-glycoprotein interactions of a series of potentially CNS-active 
Amaryllidaceae alkaloids. Journal of Pharmacy and Pharmacology. doi: 10.1111/j.20427158.2012.01536.x. (In press)

Fang, L., Kraus, B., Lehmann, J., Heilmann, J., Zhang, Y., Decker, M., 2008. Design and synthesis of tacrine-ferulic acid hybrids as multi-potent anti-Alzheimer drug candidates. Bioorganic and Medicinal Chemistry Letters 18, 2905-2909.

Ferreira, A., Proença, C., Serralheiro M.L.M., Araújo, M.E.M., 2006. The in vitro screening for acetylcholinesterase inhibition and antioxidant activity of medicinal plants from Portugal. Journal of Ethnopharmacology 108, 31-37.

Francis, P.T., Palmer, A.M., Snape, M., Wilcock, G.K., 1999. The cholinergic hypothesis of Alzheimer's disease: a review of progress. Journal of Neurology Neurosurgery and Psychiatry 66, 137-147.

Hansen, M.B., Nielsen, S.E., Berg, K., 1989. Re-examination and further development of a precise and rapid dye method for measuring cell growth/cell kill. Journal of Immunological Methods 119, 203-210.

Hautch, H., Stauffacher, D., 1961. Die alkaloide von Buphane disticha (L.f.) Herb. Helvetica Chimica Acta 44, 491-502.

Heinrich, M., Teoh, H.L., 2004. Galanthamine from snowdrop - the development of a modern drug against Alzheimer's disease from local Caucasian knowledge. Journal of Ethnopharmacology 92, 147-162. 
Kawahami, K., Kadota, J., Iida, K., Shirai, R., Abe, K., Kohno, S., 1999. Reduced immune function and malnutrition in the elderly. The Tohoku Journal of Experimental Medicine $187,157-171$.

Knapp, M.J., Knopman, D.S., Solomon, P.R., Pendlebury, W.W., Davis, C.S., Gracon, S.I., 1994. A 30-week randomized controlled trial of high-dose tacrine in patients with Alzheimer's disease. The Tacrine Study Group. The Journal of the American Medical Association 271, 985-991.

Konrath, E.L., Neves, B.M., Lunardi, P.S., Passos, C., Simões-Pires, A., Ortega, M.G., Gonçalves, C.A., Cabrera, J.L., Moreira, J.C.F., Henriques, A.T., 2012. Investigation of the in vitro and ex vivo acetylcholinesterase and antioxidant activities of traditionally used Lycopodium species from South America on alkaloid extracts. Journal of Ethnopharmacology 139, 58-67.

Likhitwitayawuid, K., Angerhofer, C.K., Chai, H., Pezzuto, J.M., Cordell, G.A., 1993. Cytotoxic and antimalarial alkaloids from the bulbs of Crinum amabile. Journal of Natural Products $56,1331-1338$.

Min, B.S., Gao, J.J., Nakamura, N., Kim, Y.H., Hattori, M., 2001. Cytotoxic alkaloids and a flavan from the bulbs of Crinum asiaticum var. japonicum. Chemical and Pharmaceutical Bulletin 49, 1217-1219.

Mossmann, T., 1983. Rapid colorimetric assay for cellular growth and survival. Application to proliferation and cytotoxicity assays. Journal of Immunological Methods 65, 55-63. 
Neergaard, J.S., Andersen, J., Pedersen, M.E., Stafford, G.I., van Staden, J., Jäger, A.K., 2009. Alkaloids from Boopone disticha with affinity to the serotonin transporter. South African Journal of Botany 75, 371-374.

Pallant, C.A., 2010. Masters thesis, Bioactivity of the alkaloidal fraction of Tabernaemontana elegans (Stapf.). University of Pretoria, Pretoria, South Africa.

Pajouhesh, H., Lenz, G.R., 2005. Medicinal chemical properties of successful central nervous system drugs. Neurotherapeutics 2, 541-553.

Rhee, I.K., van Rijn, R.M., Verpoorte, R., 2003. Qualitative determination of false-positive effects in the acetylcholinesterase assay using thin layer chromatography. Phytochemical Analysis $14,127-131$.

Sandager, M., Nielsen, N.D., Stafford, G.I., van Staden, J., Jäger, A.K., 2005. Alkaloids from Boophane disticha with affinity to the serotonin transporter in rat brain. Journal of Ethnopharmacology 98, 367-370.

Silva, B.A., Dias, A.C.P., Ferreres, F., Malva, J.O., Oliveira, C.R., 2004. Neuroprotective effect of $H$. perforatum extracts on $\beta$-amyloid induced neurotoxicity. Neurotoxicity Research 6 , 119-130.

Sobiecki, J.F., 2002. A preliminary inventory of plants used for psychoactive purposes in southern African healing traditions. Transactions of the Royal Society of South Africa 57, 1-24.

Thompson, S., Lanctot, K.L., Herrmann, N., 2004. The benefits and risks associated with cholinesterase inhibitor therapy in Alzheimer's disease. Expert Opinion on Drug Safety $3,425-440$. 
Tram, N.T.N., Titorenkova, Tz.V., Bankova, B.St., Handjieva, N.V., Popov, S.S., 2002. Crinum (Amaryllidaceae). Fitoterapia 73, 183-208.

Van Tonder, J.J., 2011. Doctoral thesis, Development of an in vitro mechanistic toxicity screening model using cultured hepatocytes. University of Pretoria, Pretoria, South Africa.

Van Wyk, B., Gericke, N., 2000. Peoples Plants. Briza Publications, Pretoria, South Africa.

Viladomat, F., Almanza, G.R., Codina, C., Bastida, J., Campbell, W.E., Mathee, S., 1996. Alkaloids from Brunsvigia orientalis. Phytochemistry 43, 1379-1384.

Wink, M., 2000. Interference of alkaloids with neuroreceptors and ion channels. In: Atta-urRahman, editor. Amsterdam, Elsevier Science, 3-122.

Wrinkle, G., 1984. An introduction to the genus Boophane. Herbatia 40, 77-82.

Xie, H-R., Hu, L-S., Li, G-Y., 2010. SH-SY5Y human neuroblastoma cell line: in vitro cell model of dopaminergic neurons in Parkinson's disease. Chinese Medical Journal 123, 1086-1092.

Yu, M-S., Leung, S.K-Y., Lai, S-W., Che, C-M., Zee, S-Y., So, K-F., Yuen, W-H., Chang, R.CC., 2005. Neuroprotective effects of anti-aging oriental medicine Lycium barbarum against $\beta$-amyloid peptide neurotoxicity. Experimental Gerontology 40, 716-727.

Zvetkova, E., Wirleitner, B., Tram, N.T., Schennach, H., Fuchs, D., 2001. Aqueous extracts of Crinum latifolium and Camellia sinensis show immunomodulatory properties in human peripheral blood mononuclear cells. International Immunopharmacology 1, 2143-2150. 


\section{Figure Legends}

Figure 1 Structures of several alkaloids previously isolated from the bulbs of Boophane disticha.

Figure 2 Schematic diagram showing the isolation of 6-hydroxycrinamine from the methanol extract of the bulbs of Boophane disticha.

Figure 3 Structure of 6-hydroxycrinamine showing its two epimers.

Figure 4 Effect of 6-hydroxycrinamine on the viability of SH-SY5Y cell lines as measured by (A) MTT and (B) neutral red uptake assays after $72 \mathrm{~h}$ of incubation.

\section{Table Legends}

Table $1{ }^{1} \mathrm{H}$ NMR data for 6-hydroxycrinamine in methanol- $\mathrm{d}_{4}\left(\mathrm{CD}_{3} \mathrm{OD}\right)$.

Table $2{ }^{13} \mathrm{C}$ NMR data for 6-hydroxycrinamine in methanol- $\mathrm{d}_{4}\left(\mathrm{CD}_{3} \mathrm{OD}\right)$. 


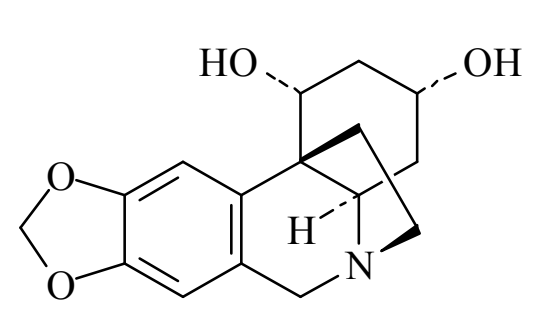

Buphanitine (Nerbowdine)

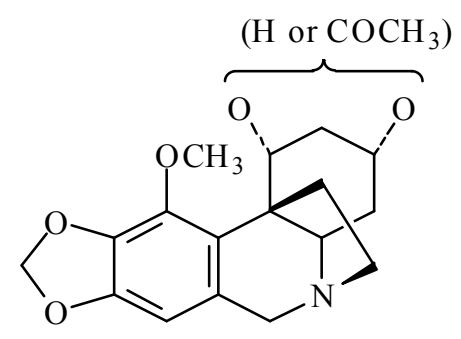

Acetyl- Nerbowdine

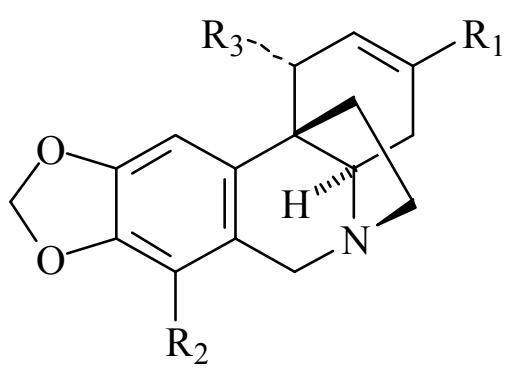

Buphanamine where $\mathrm{R}_{1}=\mathrm{H}, \mathrm{R}_{2}=\mathrm{OMe}, \mathrm{R}_{3}=\mathrm{OH}$

Distichamine where $\mathrm{R}_{1}=\mathrm{OMe}, \mathrm{R}_{2}=\mathrm{OMe}, \mathrm{R}_{3}=\mathrm{O}$

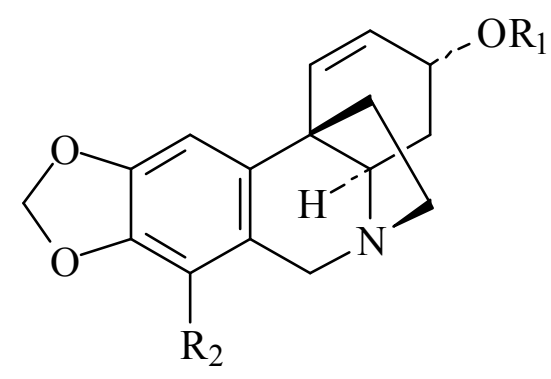

Crinine where $\mathrm{R}_{1}=\mathrm{R}_{2}=\mathrm{H}$

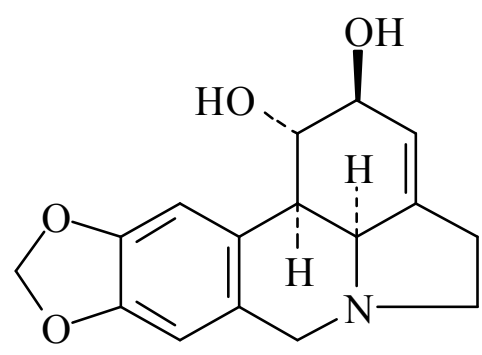

Lycorine

Buphanidrine where $\mathrm{R}_{1}=\mathrm{CH}_{3}, \mathrm{R}_{2}=\mathrm{OCH}_{3}$

Buphanisine where $\mathrm{R}_{1}=\mathrm{OCH}_{3}, \mathrm{R}_{2}=\mathrm{H}$ 


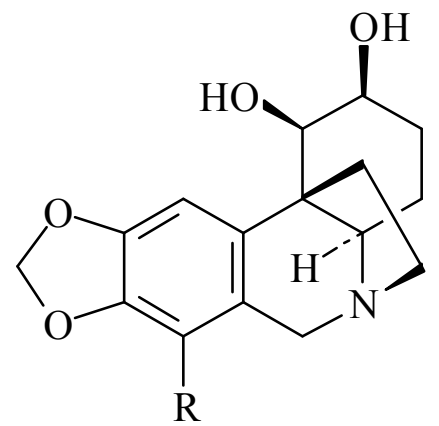

$4 \alpha$-Dehydroxycrinamabine where $\mathrm{R}=\mathrm{H}$

Undulatine where $\mathrm{R}=\mathrm{CH}_{3}$

Figure 1 


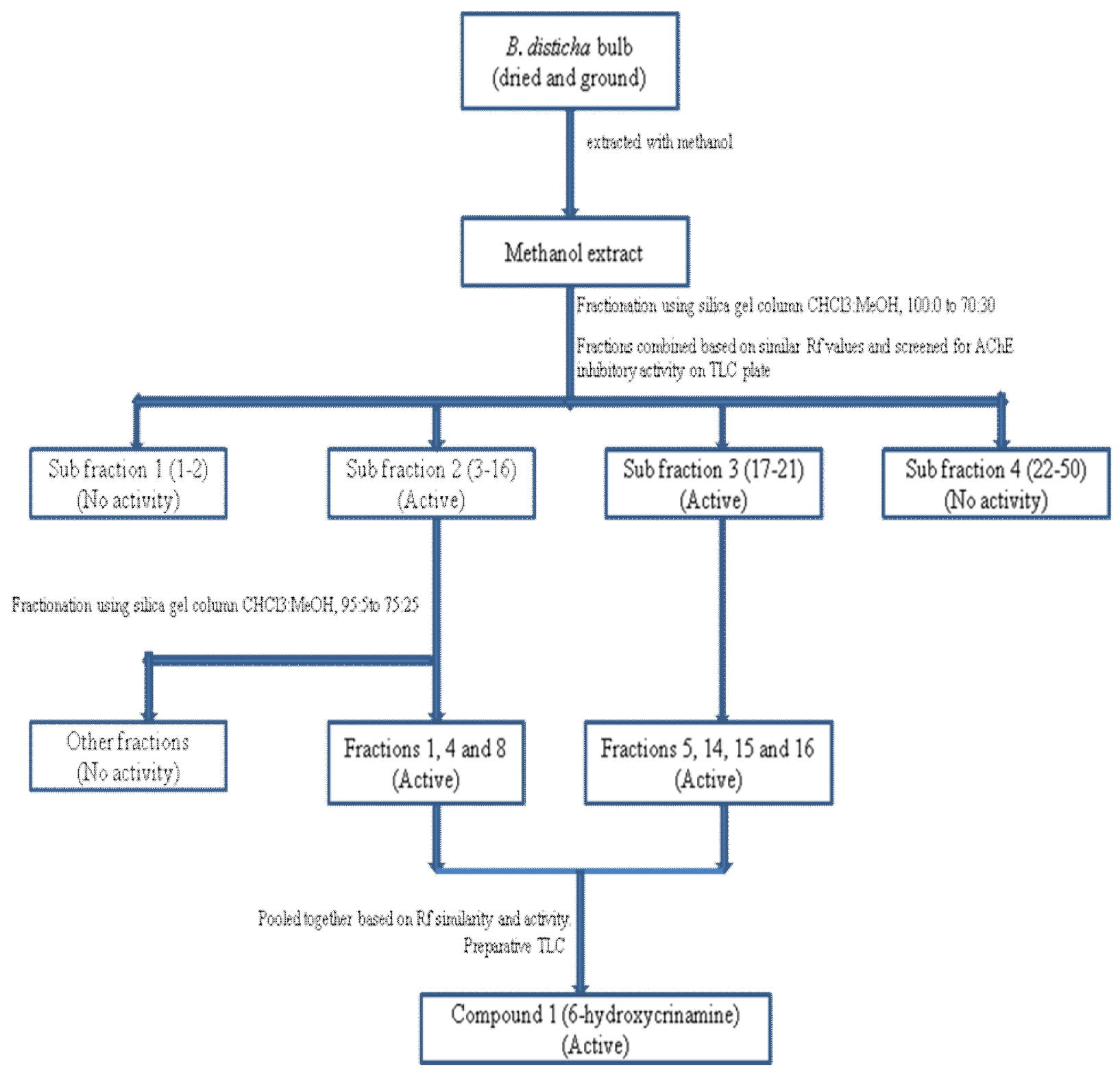

Figure 2 


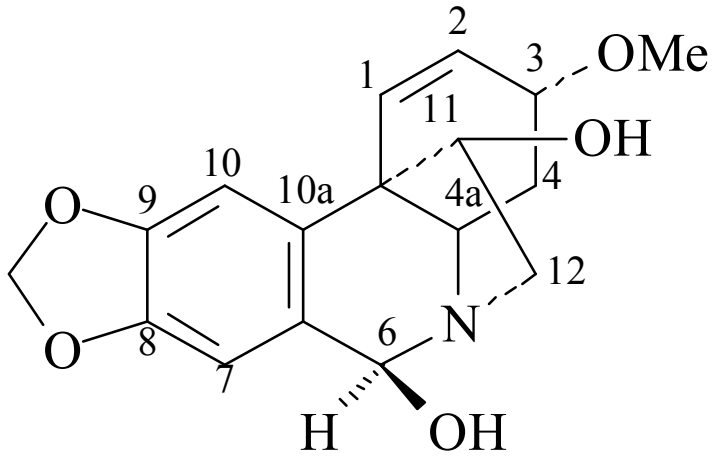

Epimer A (6a-hydroxycrinamine) (1)

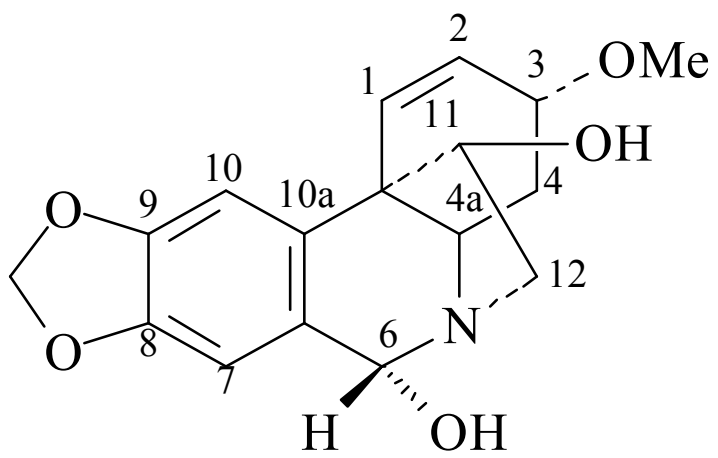

Epimer B (6ß-hydroxycrinamine) (2)

Figure 3 

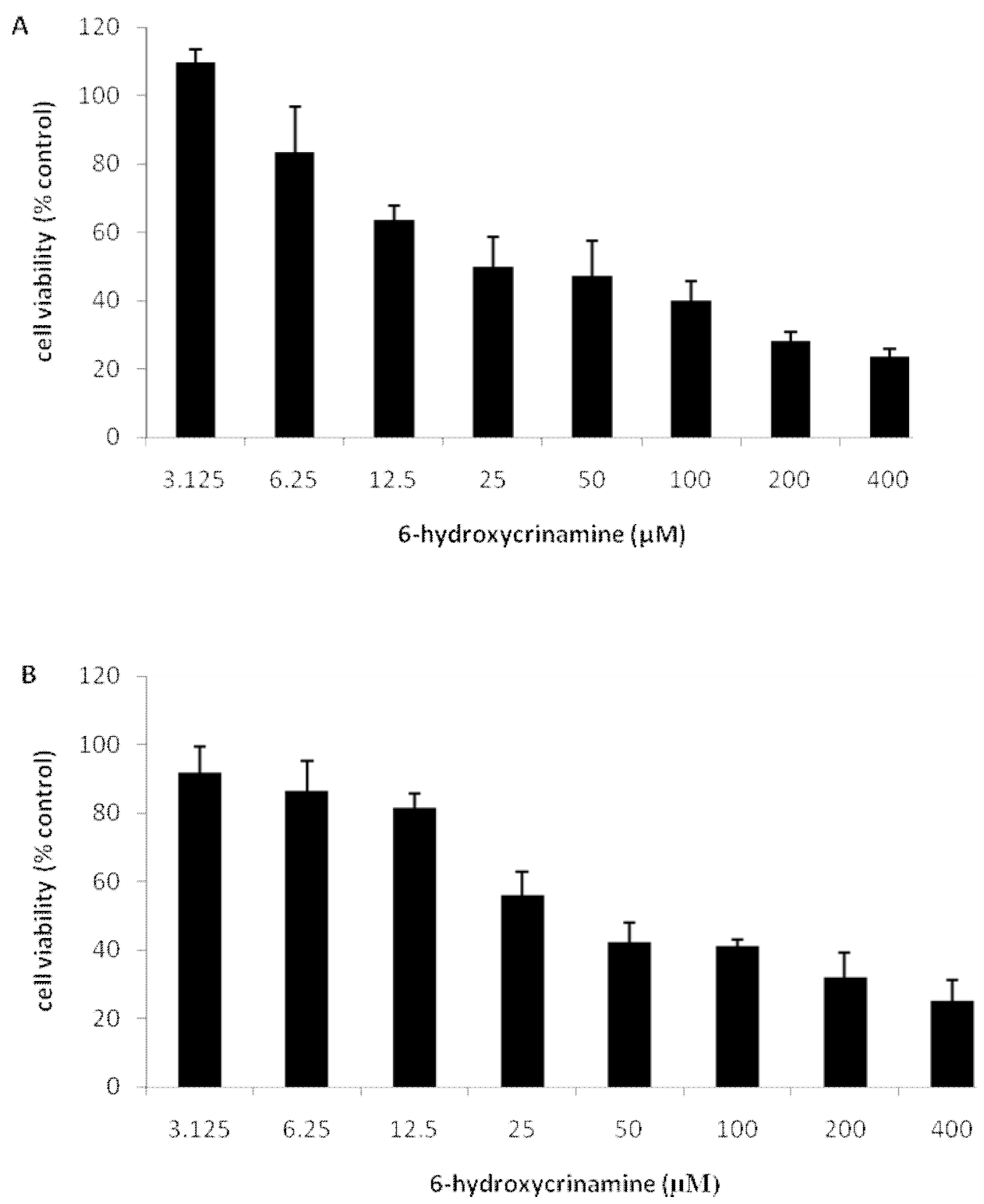

Figure 4 


\section{Table 1}

\begin{tabular}{|c|c|c|}
\hline $\mathbf{H}$ & $\begin{array}{l}\text { 6a-hydroxycrinamine } \\
(\text { Epimer } A), \delta_{H} \\
(J \text { in } \mathrm{Hz})\end{array}$ & 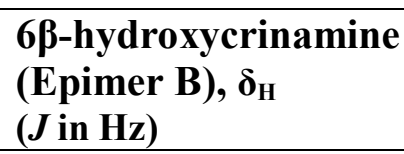 \\
\hline 1 & $6.22 \mathrm{~m}$ & $6.22 \mathrm{~m}$ \\
\hline 2 & $6.22 \mathrm{~m}$ & $6.22 \mathrm{~m}$ \\
\hline 3 & $4.02 \mathrm{~m}$ & $4.02 \mathrm{~m}$ \\
\hline $4 \alpha$ & $2.14 \mathrm{~m}$ & $2.26 \mathrm{~m}$ \\
\hline $4 \beta$ & $2.07 \mathrm{~m}$ & $2.16 \mathrm{~m}$ \\
\hline $4 \mathrm{a}$ & $3.71 \operatorname{brdd}(12.9,5.0)$ & $3.42 \mathrm{~m}$ \\
\hline 6 & $5.01 s$ & $5.60 s$ \\
\hline 7 & $6.80 s$ & $6.96 s$ \\
\hline 10 & $6.75 s$ & $6.73 s$ \\
\hline 11 & $3.89 \mathrm{~m}$ & $3.89 \mathrm{~m}$ \\
\hline 12 endo & $3.36 \mathrm{brd}$ & $4.19 d d(14.1,6.5)$ \\
\hline 12 exo & $3.33 d d(14.1,2.9)$ & $3.02 \mathrm{brd}$ \\
\hline $\mathrm{OCH}_{2} \mathrm{O}$ & $5.90 \mathrm{brd}$ & $5.90 \mathrm{brd}$ \\
\hline $3-\mathrm{OMe}$ & $3.39 s$ & $3.39 s$ \\
\hline
\end{tabular}


Table 2

\begin{tabular}{|l|l|l|}
\hline Carbon atom & $\begin{array}{l}\text { 6a-hydroxycrinamine } \\
\text { (Epimer A), } \boldsymbol{\delta}_{\mathbf{C}} / \mathbf{p p m}\end{array}$ & $\begin{array}{l}\mathbf{6} \boldsymbol{\beta} \text {-hydroxycrinamine } \\
\text { (Epimer } \mathbf{B}), \boldsymbol{\delta}_{\mathbf{C}} / \mathbf{p p m}\end{array}$ \\
\hline 1 & 136.9 & 136.8 \\
\hline 2 & 123.3 & 123.1 \\
\hline 3 & 76.2 & 75.8 \\
\hline 4 & 29.8 & 29.6 \\
\hline 6 & 88.4 & 85.9 \\
\hline $6 \mathrm{a}$ & 127.5 & 127.5 \\
\hline 7 & 109.7 & 108.5 \\
\hline 8 & 147.0 & 146.8 \\
\hline 9 & 148.1 & 147.9 \\
\hline 10 & 103.1 & 103.0 \\
\hline $10 \mathrm{a}$ & 136.2 & 134.9 \\
\hline $10 \mathrm{~b}$ & 51.1 & 50.7 \\
\hline 11 & 78.4 & 79.3 \\
\hline 12 & 58.1 & 52.1 \\
\hline$-\mathrm{OCH}_{2} \mathrm{O}$ & 102.9 & 101.3 \\
\hline $3-\mathrm{OMe}$ & 56.2 & 56.2 \\
\hline
\end{tabular}

